\title{
Cyclicity of Continental Alkaline Magmatism in the Geological Record
}

Taylor, W.R. ${ }^{1}$ and J. Bristow, J. ${ }^{2}$

${ }^{1}$ R.S.E.S., Australian National University, Canberra, A.C.T. 0200, Australia
2 CIGARD Geological Services, P.O.Box 1038, Cresta 2118, Gauteng, South Africa

In continental settings, alkaline rocks are known from rift-zones, post-collisional continental margins, ancient orogenic zones and the interiors of cratons stabilized in the Precambrian. Although often volumetrically small, alkaline rock complexes are of considerable economic significance yielding important deposits of rare metals (e.g. Nb, Zr, REE) and industrial minerals (e.g. fluorite, apatite). On a regional or province scale, alkaline rocks of direct upper mantle derivation, such as kimberlite and olivine lamproite, are often spatially, but not necessarily temporally, associated with differentiated alkaline rock complexes that may include peralkaline granite, syenite, and carbonatite. Continental regions that are host to kimberlites and lamproites typically have been the focus of a number of alkaline magmatic events through time. Age relationships of alkaline rocks can therefore provide important insights into their petrogenesis, tectonic setting and the history of the subcontinental mantle from which they ultimately originated.

On a global scale, it has been shown that alkaline magmatism, and in particular kimberlitic magmatism, is most strongly concentrated during certain periods of Earth history. Because of the availability of several recent compilations containing age data for alkaline rock complexes and the availability of new high precision kimberlite dates (e.g. SHRIMP perovskite dating), a global database has been assembled in order to determine whether there are specific periods or patterns of alkaline magmatism through time and whether there is a temporal relationship between felsic and carbonatitic alkaline magmatism and more deep-seated kimberlite magmatism.
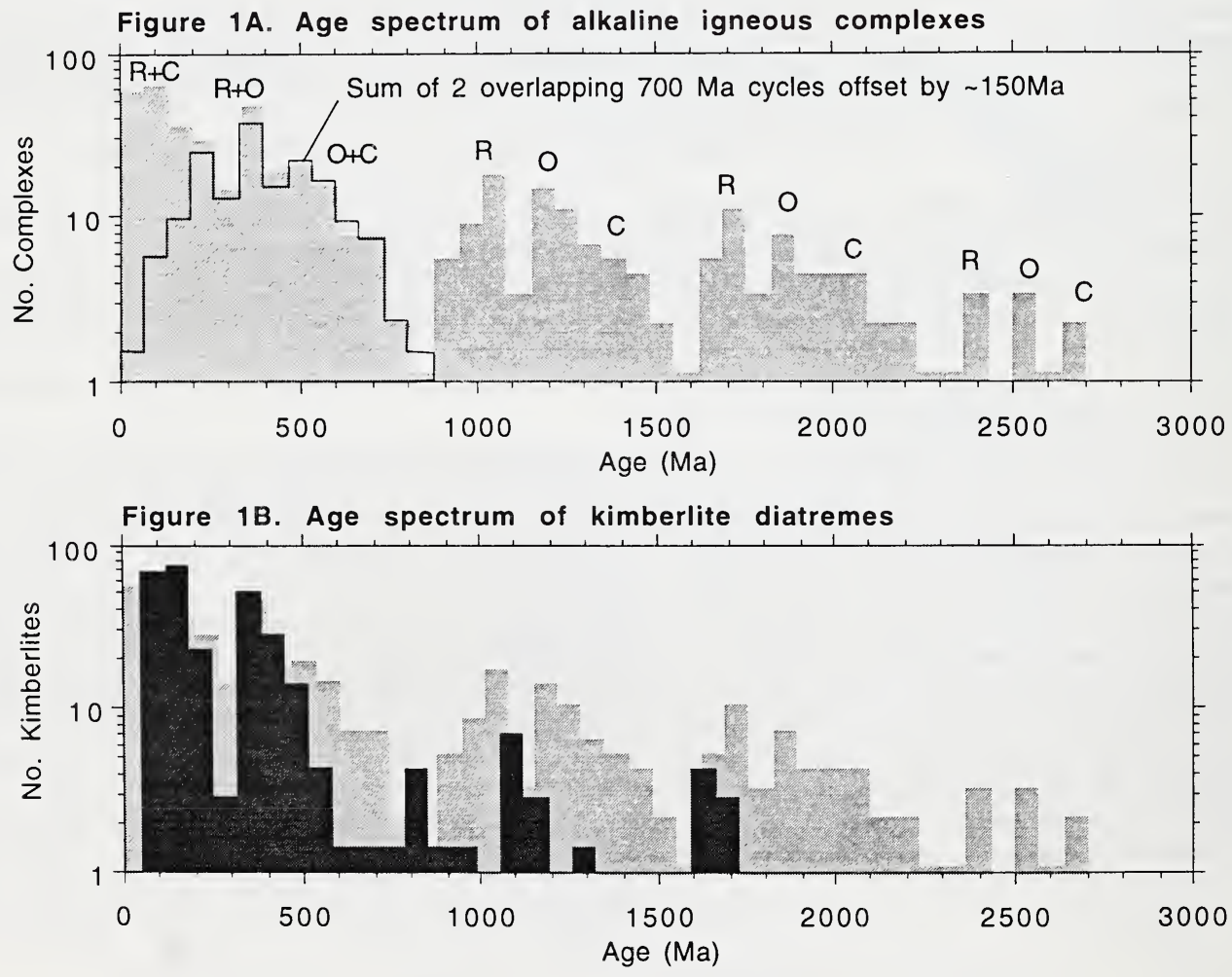
The results, displayed in Figure $1 \mathrm{~A}$, show a remarkable $\sim 700$ Ma cyclicity in alkaline magmatism and an approximately exponential increase in the extent of alkaline magmatism since the late Archean. This may in part reflect poor preservation of older alkaline complexes but also may relate to the relative abundance of thick, cool subcontinental lithosphere and overall cooling of the mantle with time, both of which would favour production of smalldegree, volatile-rich mantle melts. The $\sim 700$ Ma cycles appear to be comprised of three phases of magmatism that may relate to the mantle-driven formation and break-up of supercontinents. The post-800 Ma cycle is more complex than the older cycles but can be resolved into two complete cycles offset by $\sim 150 \mathrm{Ma}$ plus the 'tail' of a third, more recent, cycle. There are major peaks in alkaline magmatism at $\sim 2.55,1.85,1.17$ and $0.45-0.35 \mathrm{Ga}$ [Phase O] which are dominated by rocks of potassic or shoshonitic character and appear to correspond to the "postcollisional' period immediately following major global orogenies at $\sim 2.7 \mathrm{Ga}$ (Late Archean), $\sim 1.9 \mathrm{Ga}$ (Early Proterozoic), $\sim 1.3-1.2 \mathrm{Ga}$ (Grenvillean), 0.5-0.4 Ga (Pan-African, Caledonian). Strong peaks in alkaline magmatism at $\sim 2.4,1.7,1.05$ and $0.23-0.16 \mathrm{Ga}$ [Phase $\mathrm{R}$ ] may correspond to periods of intracontinental rifting within the supercontinents. A more extended phase of alkaline magmatism [Phase C], often of carbonatitic character, at $\sim 2.05$, $1.35,0.7-0.55$ and $0.13-0.05 \mathrm{Ga}$ may be linked to the latter part of supercontinent break-up and drift of rifted continental fragments.

With the exception of $\sim 820$ Ma North Australian kimberlites, global peaks in kimberlitic magmatism seem to correspond to peaks in alkaline magmatism which involve Phase $\mathrm{R}$ but perhaps slightly offset to older or younger ages depending on geographic location (Fig. 1B). There are well recognized peaks at $\sim 1.7 \mathrm{Ga}, 1.15 \mathrm{Ga}, 0.95 \mathrm{Ga}, 0.4-0.35 \mathrm{Ga}$ and $0.2-0.08 \mathrm{Ga}$. Interestingly, kimberlites are not known from the Proterozoic periods corresponding to Phase $\mathrm{C}$ (dominantly carbonatitic) alkaline magmatism.

The cyclicity of alkaline magmatism since the late Archaen suggest control by global tectonic processes involving formation and destruction of supercontinents. Kimberlite genesis seems to be linked to specific intervals in the cycles of general alkaline magmatism. 